\title{
MIR7-2 wt Allele
}

National Cancer Institute

\section{Source}

National Cancer Institute. MIR7-2 wt Allele. NCI Thesaurus. Code C81864.

The human MIR7-2 wild-type allele is located in the vicinity of 15q26.1 and is 109 bases in length. This allele, which encodes MIR7 RNA, plays a role in lung and breast cancers. 